\title{
Effect of different double-sided plastic films on chemical and fermentation characteristics of corn silage
}

\section{Efeito de diferentes filmes plásticos dupla face sobre características quimíco- fermentativas da silagem de milho}

Fernando Braga Cristo ${ }^{*}$ (D) , Mikael Neumann ${ }^{1}$ (D) , Fernando de Souza Sidor ${ }^{1}$, Maria Eduarda Cozechen Seller ${ }^{1}$ (D) , Daniel Corrêa Plodoviski ${ }^{1}$ (D) , Everton Luiz Carneiro ${ }^{1}$ (D) , Paulo Victor Pinheiro Cesar ${ }^{1}$ (D) Leticia Santos Savoldi ${ }^{1}$ (D, Luísa da Costa ${ }^{1}$

${ }^{1}$ Universidade Estadual do Centro-Oeste, Guarapuava, PR, Brazil

*Correspondent - fernandobragacristo@gmail.com

Received

November 24, 2020

Accepted

April 12, 2021.

Published

July 23, 2021.

www.revistas.ufg.br/vet visit the website to get the how to cite in the article page.

\section{Abstract}

The objective of this study was to evaluate the efficiency of different double-sided plastic films on chemical and fermentation characteristics, dry matter digestibility, aerobic stability, physical and dry matter losses in corn silages stored in bunker silos. This was a completely randomized experimental design consisting of three treatments: DF110 $\mathrm{mm}$

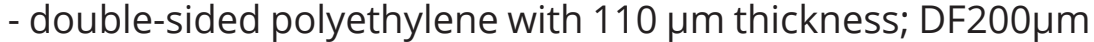
- double-sided polyethylene with $200 \mu \mathrm{m}$ thickness; and DFBO - oxygen-impermeable film consisted of double-sided polyethylene with $80 \mu \mathrm{m}$ thickness overlaid with a translucent vacuum polyamide film with $20 \mu \mathrm{m}$ thickness. The use of DF200 $\mu \mathrm{m}$ film increased the ruminal dry matter digestibility by $4.58 \%$ and reduced the silage temperature by $3.1{ }^{\circ} \mathrm{C}$, as well as the physical losses of the corn silage were reduced by $118.9 \mathrm{~g} \mathrm{~kg}^{-1}$ DM using DFBO and $95 \mathrm{~g} \mathrm{~kg}^{-1}$ DM with DF200 $\mu \mathrm{m}$; DFBO resulted in the highest aerobic stability (127 hours) of corn silage. The use of DF200 $\mu \mathrm{m}$ and DFBO is recommended for preserving corn silage in bunker silos.

Keywords: Oxygen barrier. Dry matter digestibility. Aerobic stability. Dry matter losses. Polyamide.

\section{Resumo \\ O objetivo deste trabalho foi avaliar a eficiência de diferentes filmes plásticos dupla face sobre as características quimiofermentativas, digestibilidade da matéria seca, estabilidade aeróbica, perdas físicas e de matéria seca de silagens de milho armazenadas em silos trincheira. O delineamento experimental utilizado foi inteiramente casualizado, compostos por três tratamentos: DF110 $\mu \mathrm{m}$ - polietileno dupla face com espessura de $110 \mu \mathrm{m}$; DF200 $\mu \mathrm{m}$ - polietileno dupla face com espessura de $200 \mu \mathrm{m}$; e DFBO - película impermeável ao oxigênio composta de polietileno dupla face com espessura de $80 \mu \mathrm{m}$ sobreposta a uma película de poliamida translúcida a vácuo com espessura de $20 \mu \mathrm{m}$. O uso do filme DF200 $\mu$ m aumentou em 4,58\% a digestibilidade ruminal da matéria seca e reduziu em $3,1^{\circ} \mathrm{C}$ a temperatura da silagem, assim como as perdas físicas da silagem de milho}


foram reduzidas em 118,9 $\mathrm{g} \mathrm{kg}^{-1}$ da MS pela utilização do DFBO e $95 \mathrm{~g}$

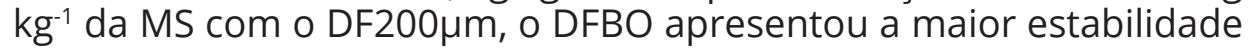
aeróbica (127 horas) da silagem de milho. O uso de filme DF200 $\mu \mathrm{m}$ e DFBO é recomendado para conservação de silagem de milho em silos do tipo trincheira.

Palavras-chave: Barreira de oxigênio. Digestibilidade da matéria seca. Estabilidade aeróbica. Perdas de matéria seca. Poliamida.

\section{Introduction}

Corn silage is the forage most used for feeding feedlot cattle, due to its excellent potential for dry matter production and nutritional value ${ }^{(1)}$. However, the ensiling process requires specific conditions for a correct fermentation and preservation of this forage, especially in obtaining an anaerobic environment in the storage silo(2).

Obtaining anaerobiosis inside the silo is dependent on numerous factors ${ }^{(3)}$, and the sealing and choice of plastic film used in the silo are closely linked to the chemical quality and digestibility of the resulting silage, directly impacting the use and performance of the animals $s^{(4,5,6,7)}$.

Using polyethylene-based plastic films to seal silos was considered a major milestone in the production of preserved food, allowing the isolation of food deposited in the silo from variations in temperature, rainfall and oxygen ${ }^{(4)}$. Quality plastic films must be impermeable to oxygen and water, have good insulating capacity, be resistant and with high durability, essential attributes in sealing(8).

However, the isolated use of polyethylene is incapable of totally blocking oxygen, which can generate changes during the fermentation process and silage preservation, resulting in aerobic deterioration that leads to significant losses ${ }^{(9)}$. Seeking to solve this problem, the combination of plastic polymers such as polyamide with polyethylene, through the extrusion process, has become an alternative, as it combines the barrier capacity of polyamide with the good mechanical resistance of polyethylene ${ }^{(3)}$.

Measuring the losses generated by inefficiency in the sealing system has become essential to achieve success in production systems, in which silage is used as the main forage, but there are few studies that investigate the influence of the type of sealing in beef cattle production systems in Brazil.

Therefore, the objective of this study was to evaluate the sealing efficiency with different double-sided plastic films on chemical and fermentation characteristics, dry matter digestibility, aerobic stability, physical and dry matter losses of corn silages stored in bunker silos.

\section{Material and methods}

All experimental procedures were previously subjected to the UNICENTRO Committee for Ethical Use of Experimental Animals (CEUA), and approved for execution (Official 


\section{Letter 021/2018).}

The experiment was carried out at the Center for Animal Production of the State University of the Center-West, in the municipality of Guarapuava, state of Paraná, and according to the Köppen classification, the climate is Cfb, humid mesothermal subtropical, without a dry season, with fresh summers and moderate winter, at an altitude of approximately 1,100 $\mathrm{m}$, with an average annual rainfall of 1,944 mm, an average minimum annual temperature of $12.7^{\circ} \mathrm{C}$ and a maximum annual average of $23.5^{\circ} \mathrm{C}$, with a relative humidity of $77.9 \%$.

The soil of the experimental area was classified as Dystroferric Red Latosol (10), and the area of corn cultivation has been used in recent years with annual cycle pastures in the winter and corn crops in the summer, receiving each growing season, fertilization with nitrogen, phosphorus and potassium, according to the recommendations of the Brazilian Society of Soil Science ${ }^{(11)}$.

The corn (Zea mays, L.) crop was planted on 11/02/2017, using seeds of the hybrid Maximus Viptera $3\left(\right.$ Syngenta $\left.{ }^{\circledR}\right)$, early cycle, for grain and silage production, with hard textured grains and Glyphosate resistance biotechnology. Sowing was performed in no-till system, using a spacing between rows of $0.80 \mathrm{~m}$, sowing depth of $0.04 \mathrm{~m}$ and distribution of 5 seeds per linear meter, aiming at a final population of 62,500 thousand plants ha-1.

Basal fertilization consisted of the application of $500 \mathrm{~kg} \mathrm{ha}^{-1}$ fertilizer 12-31-17 (NPK) and the top dressing with $500 \mathrm{~kg} \mathrm{ha}^{-1}$ with the Nitrosulfocalcium fertilizer formula 27-00-00 $+\mathrm{S}$, which contains $27 \% \mathrm{~N}, 5 \% \mathrm{Ca}$ and $3.7 \% \mathrm{~S}$ in its composition, being the commercial product Yara Bela Plus ${ }^{\circledR}$. The management prior to the implantation of the corn crop was based on the control of undesirable plants and insects using the herbicide based on Glyphosate (Roundup WG ${ }^{\circledR}: 2 \mathrm{~kg} \mathrm{ha}^{-1}$ ), Imidacloprid + Beta-cyfluthrin (Connect ${ }^{\circledR}: 0.75$ $\mathrm{L} \mathrm{ha}^{-1}$ ) and mineral oil (Nimbus ${ }^{\circledR}: 0.5 \mathrm{~L} \mathrm{ha}^{-1}$ ). In the post-emergence control, Atrazine + Simazine (Primatop ${ }^{\circledR}: 3 \mathrm{~L} \mathrm{ha}^{-1}$ ), Nicosulfuron (Nortox ${ }^{\circledR}: 0.7 \mathrm{~L} \mathrm{ha}^{-1}$ ) and Alph-cypermethrin (Imunit ${ }^{\circledR}$ ) were used: $0.18 \mathrm{~L} \mathrm{ha}^{-1}$ ), through technical report of the crop. The insecticide applied was Thioacetimidate $216 \mathrm{~g} \mathrm{~L}^{-1}+$ Methanol $383.5 \mathrm{~g} \mathrm{~L}^{-1}$ (Bazuka ${ }^{\circledR} 216 \mathrm{SL}$ at a dose of $\left.0.60 \mathrm{~L} \mathrm{ha}^{-1}\right)$.

Before silage making, samples of the whole plant and structural components: stalk, leaves, bracts plus cob and grains (original material), at the reproductive stage R5 (hard grain), were homogeneously and representatively obtained, weighed and pre-dried in a forced air oven at $55^{\circ} \mathrm{C}$. After 72 hours of drying, they were weighed again to determine the dry matter content (DM), according to $A O A C^{(12)}$. This procedure allowed to estimate the potential for green biomass production $\left(\mathrm{kg} \mathrm{ha}^{-1}\right)$ and ensilable dry matter $\left(\mathrm{kg} \mathrm{ha}^{-1}\right)$, as well as the physical structure of the plant and its dry matter values and its structural components for agronomic characterization of the crop. The first ear insertion height, the plant height $(\mathrm{m})$ and the number of dry leaves per plant were also determined (Table 1). 
Table 1. Agronomic characterization of the corn plant at the time of ensiling (2017/2018 harvest)

\begin{tabular}{ll}
\hline Parameter & Mean value \\
\hline Green biomass production $\left(\mathrm{kg} \mathrm{ha}^{-1}\right)$ & 63,953 \\
Dry biomass production $\left(\mathrm{kg} \mathrm{ha}^{-1}\right)$ & 23,944 \\
First ear insertion height $(\mathrm{m})$ & 1.22 \\
Plant height $(\mathrm{m})$ & 2.15 \\
Number of dry leaves per plant & 4.68 \\
Dry matter content $\left(\mathrm{g} \mathrm{kg}^{-1}\right)$ : & 201.70 \\
Stalk & 307.30 \\
Leaves & 355.70 \\
Bracts & 359.00 \\
Cob & 651.30 \\
Grains & 374.30 \\
Whole plant & 262.10 \\
Grainless plant & \\
Physical composition of the plant $\left(\mathrm{g} \mathrm{kg}^{-1}\right)$ : & 153.40 \\
Stalk & 255.80 \\
Leaves & 105.70 \\
Bracts & 83.50 \\
Cob & 506.40 \\
\hline
\end{tabular}

Corn plants were harvested 145 days post-emergence, at a hard grain phenological stage (R5), with the aid of a precision forage harvester JF ${ }^{\circledR}$ C-120 AT S2, with a cutting height of $20 \mathrm{~cm}$ and regulation of average particle size with a proportion of $2.5 \%$ in the first sieve $(>1.9 \mathrm{~cm}), 52.5 \%$ in the second sieve $(1.9-0.7 \mathrm{~cm})$ and $44.0 \%$ in the third sieve $(<0.7 \mathrm{~cm})$.

The experimental design used was completely randomized, consisting of three treatments: DF110 $\mu \mathrm{m}$ - double-sided polyethylene with $110 \mu \mathrm{m}$ thickness; DF200 $\mu \mathrm{m}$ - double-sided polyethylene with $200 \mu \mathrm{m}$ thickness; and DFBO - oxygen-impermeable film composed of double-sided polyethylene with $80 \mu \mathrm{m}$ thickness overlaid with a translucent vacuum polyamide film with $20 \mu \mathrm{m}$ thickness, with four repetitions each.

Treatment DF110 $\mu$ m consisted of the use of a double-sided plastic film, made of 110 $\mu \mathrm{m}$ thick polyethylene, Plus Agrolord ${ }^{\circledR}$, Basso Pancote company. Treatment DF200 $\mu \mathrm{m}$ consisted of the use of a double-sided polyethylene plastic film with $200 \mu \mathrm{m}$ thickness, Carga Pesada ${ }^{\circledR}$. For the DFBO treatment, the plastic film Polydress ${ }^{\circledR} \mathrm{O}_{2}$ Barrier 2IN1, RKW company, which has an $80 \mu \mathrm{m}$ layer of a protective film composed of polyethylene, overlaid with a layer of translucent vacuum polyamide film with $20 \mu \mathrm{m}$ thickness, which guarantees the impermeability to oxygen.

Silos were opened at the same time 75 days after ensiling, the management during the feed-out consisted of a daily removal of $0.15 \mathrm{~m}$ and the feed-out period took place for 100 days. The silos used were bunker silos, with each silo consisting of one repetition; 12 bunker silos 15 meters long, 1.2 meters high and 1.2 meters wide were used. 
To estimate dry matter losses, 24 bags were placed inside the experimental silos during ensiling as proposed by Neumann et al.(13). Bags were distributed according to each treatment and each repetition. They were homogeneously filled with original material and known weight. The designation of bags refers to a $100 \%$ polyamide malleable nylon bag, with 85 micrometer pores, dimensions of $12 \mathrm{~cm} \times 50 \mathrm{~cm}$ in diameter and length, respectively. Each bag was identified, weighed individually empty and then weighed again after filling. To seal the bags, flexible PVC clamp seals were used. The final specific mass of the silage contained in the bags was subjected to the same compaction procedure as the original material contained in the silos, with the aid of a tractor, in order to ensure the same compaction between the original material in the bags and the silo.

Silage temperature was measured at 6 sites on the feed out face of each silo, at 06:00, 12:00 and 16:00 hours, as well as the ambient temperature, using a digital metal rod thermometer, timer and current reading range between -50 to $250^{\circ} \mathrm{C}$. The temperature in the silage was measured at a depth of $7 \mathrm{~cm}$ in the structured mass on the feed out face of the silos. The temperature gradient (TG) was obtained by the difference found between the ambient temperature and the temperature of the evaluated silages. In the same period, $\mathrm{pH}$ readings were also taken daily at 6:00 hours, using a benchtop digital potentiometer, according to the methodology established by Cherney and Cherney ${ }^{(14)}$.

Physical losses of the silage were estimated daily during the experimental period, by weighing the silage considered visibly deteriorated at the time of feed out, which was later discarded. Values obtained were corrected for weekly dry matter contents.

Twice a week during the evaluation period, homogeneous samples of silage from the silo feed out face were collected, weighed and pre-dried in a forced air oven at $55^{\circ} \mathrm{C}$ to constant weight, to determine the partial dry matter (DM) content, being sequentially ground in a Wiley mill, with a $1 \mathrm{~mm}$ mesh sieve. In the ground samples, the total dry matter (TDM) and mineral matter (MM) contents were determined according to Silva and Queiroz ${ }^{(15)}$.

Subsequently, the total dry matter was determined in an oven at $105^{\circ} \mathrm{C}$ for 4 hours, the crude protein (CP) by the micro Kjedahl method and the mineral matter (MM) by incineration at $550^{\circ} \mathrm{C}$ for 4 hours according to $A O A C^{(12)}$. Neutral detergent fiber (NDF) contents were obtained according to Van Soest et al. ${ }^{(16)}$ with thermostable a-amylase, and acid detergent fiber (ADF) and lignin (LIG) contents, according to Goering \& Van Soest ${ }^{(17)}$. The contents of total digestible nutrients (TDN) were calculated according to equations proposed by Bolsen et al. a $^{(18)}$. Hemicellulose contents were obtained from the difference between NDF and ADF, as well as the cellulose contents were obtained from the difference between NDF and lignin.

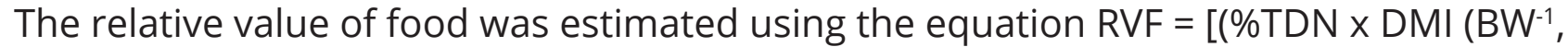
\%)/ 1.29] $\times 100$, suggested by Bolsen et al. ${ }^{(18)}$. Dry matter intake in percentage of body weight was estimated via equation ( $\left.\mathrm{DMI}\left(\mathrm{BW}^{-1}, \%\right)=120 / \mathrm{NDF}\right)$.

The ruminal dry matter digestibility and the ruminal dry matter disappearance rate of silages were estimated by the in situ technique, using nylon bags measuring $12 \mathrm{~cm} \times 8$ $\mathrm{cm}$ and with 40 to $60 \mu \mathrm{m}$ pores, containing $5 \mathrm{~g}$ dry sample of each material, ground to $1 \mathrm{~mm}$, for further incubation in the rumen ${ }^{(19)}$. The incubation times used were $0,6,12$, 
24, 36, 48 and 168 hours. For this purpose, we used two steers housed in the Didactic Unit for Beef Cattle Studies of the State University of Midwest, both 60 months old, average body weight of $650 \mathrm{~kg}$, with ruminal cannula implanted using the ruminostomy technique, previously approved by the Committee for Ethical Use of Experimental Animals (CEUA/UNICENTRO), under the official letter 030/2014.

The fermentation profile was determined according to the methodology described by Price ${ }^{(20)}$. The concentration of acetic acid in samples was determined by gas chromatography, using a Shimadzu ${ }^{\odot}$ GC-2010 Plus chromatograph equipped with AOC20i automatic injector, Stabilwax-DA ${ }^{\mathrm{TM}}$ capillary column $(30 \mathrm{~m}, 0.25 \mathrm{~mm} I \mathrm{D}, 0.25 \mu \mathrm{m}$ $\mathrm{df}, \operatorname{Restek}^{\odot}$ ) and flame ionization detector (FID), after acidifying with $1 \mathrm{M}$ phosphoric acid p.a. (Ref. 100573, Merck $^{\odot}$ ) and fortification with the WSFA-2 standard (Ref. 47056, Supelco $\left.{ }^{\circ}\right)$. The sample collected from the silage of each treatment was $15 \mathrm{~g}$, which were homogenized using a blender with $200 \mathrm{~mL}$ distilled water. After homogenization for one minute, the sample was sieved and centrifuged, and the volume of $1 \mu \mathrm{L}$ was taken. This sample was injected at a split ratio of 40:1, using helium as carrier gas at a linear velocity of $42 \mathrm{~cm} \cdot \mathrm{s}^{-1}$, obtaining the separation of the analytes in a chromatographic run of 11.5 minutes. The injector and detector temperatures were, respectively, $250^{\circ} \mathrm{C}$ and $300^{\circ} \mathrm{C}$, and the initial column temperature was $40^{\circ} \mathrm{C}$. The column temperature ramp started with a gradient from 40 to $120^{\circ} \mathrm{C}$ at the rate of $40^{\circ} \mathrm{C} \mathrm{min}^{-1}$, followed by a gradient from 120 to $180^{\circ} \mathrm{C}$ at the rate of $10^{\circ} \mathrm{C} \mathrm{min}^{-1}$ and from 180 to $240^{\circ} \mathrm{C}$ at the rate of $120^{\circ} \mathrm{C}$ $\mathrm{min}^{-1}$, keeping the temperature at $240^{\circ} \mathrm{C}$ for another 3 minutes at the end. For analyte quantification, a calibration of the method was made with dilutions of the WSFA-2 standard (Ref. 47056, Supelco ${ }^{\odot}$ ) of glacial acetic acid (Ref. 33209, Sigma-Aldrich ${ }^{\odot}$ ) and of HPLC grade ethanol (Ref. 459828, Sigma-Aldrich ${ }^{\circledR}$ ) analyzed under the conditions described above. Peak detection and integration were performed using the GCsolution 2.42.00 software (Shimadzu ${ }^{\circ}$ ).

Aerobic stability was assessed by measuring temperature and $\mathrm{pH}$. In each silo, the silage was decompressed to facilitate the exposure of the ensiled material to air, as described by Kung Jr. et al.(21), and a $400 \mathrm{~g}$ sample of the material was placed in buckets with a capacity of $1 \mathrm{~kg}$. The evaluation was carried out 50 days after silo opening. The buckets were placed in a controlled environment, with a programmed temperature to remain stable at $25^{\circ} \mathrm{C}$, throughout the evaluation period. To determine the aerobic stability, daily (at 12:00 hours), temperature and $\mathrm{pH}$ readings of the evaluated silages were taken. The evaluation time was maintained until 168 hours after the beginning of the evaluation. Temperature was measured using a long-stem digital thermometer, Gulterm 1001, inserted at the center of the silage mass and the pH readings were taken using a bench digital potentiometer, according to Cherney and Cherney ${ }^{(14)}$. The criterion for defining aerobic stability breakdown was considered when the $\mathrm{pH}$ increased to levels above 0.5 units within up to 168 hours of evaluation, as mentioned by Weinberg et al. (22). To break stability, considering temperature, it was considered as loss of aerobic stability when the temperature of the ensiled material exceeded ambient temperature by $2^{\circ} \mathrm{C}$, according to Taylor and Kung Junior ${ }^{(23)}$.

Data collected for each variable were tested by analysis of variance with comparison of means by Tukey's test at $5 \%$ significance, through the GLM procedure of SAS software ${ }^{(24)}$. The following statistical model was used: $Y i=\mu+\mathrm{Ti}+\mathrm{Ei}$, where: $Y i=$ response criterion; $\mu$ 
= overall mean common to all observations (constant); $\mathrm{Ti}=$ effect of $\mathrm{i}$-th treatment; and $\mathrm{Ei}=$ random error inherent in all observations.

\section{Results and discussion}

Table 2 lists the chemical composition data of corn silages stored in bunker silos sealed with different double-sided plastic films. The replacement of the DF110 $\mu \mathrm{m}$ film by the DF200 $\mu \mathrm{m}$ and DFBO films did not influence the chemical composition of the evaluated corn silage. In similar studies carried out by Neumann et al.(6) and Machado(25), who evaluated the nutritional composition of corn silage covered with different polyethylenebased films and oxygen barrier films, no changes in the nutritional composition of corn silage were also observed.

Literature establishes that polyethylene plastic films are permeable to oxygen ${ }^{(3)}$ and, at high ambient temperatures, their permeability is increased, increasing the entry of oxygen into the silo and increasing the loss of nutrients present in the silage, worsening the nutritional quality of the food, generating variations in the content of dry matter and crude protein in the silage ${ }^{(26)}$, but the mild temperatures typical of the region where the study was conducted may have attenuated the penetration of oxygen in the films that had only polyethylene in their composition, not causing changes in the chemical characteristics of silage.

The relative value of food differed statistically $(P<0.05)$ according to the type of sealing. Silage from the sealing with the DF200 $\mu \mathrm{m}$ film had the highest RVF value that differed from the DF110 $\mu$ m (152.5 and 149.5, respectively), while for the silage covered with DFBO, the RVF value (151.2) did not differ from other plastic films.

Table 2. Chemical composition and mean values of dry matter losses of corn silages stored in bunker silos sealed with different double-sided plastic films

\begin{tabular}{|c|c|c|c|c|c|c|}
\hline \multirow{2}{*}{ Parameter* } & \multicolumn{3}{|c|}{ Plastic Films } & \multirow{2}{*}{ Mean } & \multirow{2}{*}{$\boldsymbol{P}$} & \multirow{2}{*}{ SEM } \\
\hline & DF110um & 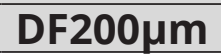 & DFBO & & & \\
\hline $\mathrm{DM}\left(\mathrm{g} \mathrm{kg}^{-1}\right)$ & $420.7 \mathrm{a}$ & $426.1 \mathrm{a}$ & $415.5 \mathrm{a}$ & 420.8 & 0.1291 & 0.1761 \\
\hline MM (g kg DM $\left.{ }^{-1}\right)$ & $23.1 \mathrm{a}$ & $23.2 \mathrm{a}$ & $24.0 \mathrm{a}$ & 23.4 & 0.6082 & 0.0393 \\
\hline $\mathrm{CP}\left(\mathrm{g} \mathrm{kg} \mathrm{DM}^{-1}\right)$ & $67.7 \mathrm{a}$ & $67.9 a$ & $72.6 \mathrm{a}$ & 69.4 & 0.2060 & 0.1128 \\
\hline $\operatorname{NDF}\left(\mathrm{g} \mathrm{kg} \mathrm{DM}^{-1}\right)$ & $536.7 \mathrm{a}$ & $529.2 \mathrm{a}$ & $535.4 a$ & 533.8 & 0.6100 & 0.3113 \\
\hline HEM (g kg DM $\left.{ }^{-1}\right)$ & $236.3 \mathrm{a}$ & $235.5 \mathrm{a}$ & $244.2 \mathrm{a}$ & 238.7 & 0.3546 & 0.2488 \\
\hline 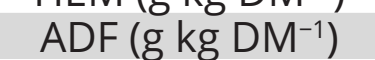 & $300.3 a$ & 293.8 a & $291.2 a$ & 295.1 & 0.2710 & 0.2113 \\
\hline CEL (g kg DM $\left.{ }^{-1}\right)$ & $248.5 \mathrm{a}$ & $243.5 \mathrm{a}$ & 239.9 a & 244.0 & 0.2067 & 0.1733 \\
\hline LIG (g kg DM $\left.{ }^{-1}\right)$ & $51.9 \mathrm{a}$ & $50.3 a$ & $51.4 \mathrm{a}$ & 51.2 & 0.7767 & 0.0919 \\
\hline DMI (\% BW) & $2.24 \mathrm{a}$ & $2.27 \mathrm{a}$ & $2.24 \mathrm{a}$ & 2.25 & 0.5511 & 0.0124 \\
\hline TDN (g kg-1) & $668.2 \mathrm{a}$ & $672.8 \mathrm{a}$ & $674.5 \mathrm{a}$ & 671.8 & 0.2667 & 0.1590 \\
\hline RVF (\% DM) & $149.5 \mathrm{~b}$ & $152.5 \mathrm{a}$ & $151.2 \mathrm{ab}$ & 151.1 & 0.0423 & 0.6499 \\
\hline DM Losses (\% DM) & $6.82 \mathrm{a}$ & $6.60 \mathrm{a}$ & $7.29 \mathrm{a}$ & 6.90 & 0.8961 & 0.4109 \\
\hline
\end{tabular}

* DM: dry matter; MM: mineral matter; CP: crude protein; NDF: neutral detergent fiber; HEM: hemicellulose; ADF: acid detergent fiber; CEL: cellulose; LIG: lignin; DMI: dry matter intake; TDN: total digestible nutrients; RVF: relative value of food; DM Losses: dry matter losses.

Means followed by different lowercase letters, in the same row, differ from each other by Tukey's Test ( $\rho$ $<0.05)$. 
The loss of dry matter of corn silages (Table 2 ) showed no significant difference ( $P>0.05)$ between the double-sided films tested, a result that differs from the expected and reported in the literature.

According to Borreani and $\mathrm{Tabacco}^{(4)}$ and Neumann et al. ${ }^{(6)}$, the reduction in dry matter losses is attributed to the impermeability of the plastic film to oxygen. Wilkinson and Fenlon ${ }^{(9)}$ reported a large variation in dry matter losses depending on the material used to seal the silos, in addition to highlighting the upper layer of the silo and/or peripheral regions as the most susceptible to DM losses, due to greater exposure to oxygen.

Bernardes et al.(27) reported that oxygen barrier films with polyamide in their composition reduced the loss of DM by 5.6 percentage points compared to sealing with polyethylenebased film. In turn, Machado ${ }^{(25)}$ found a reduction of 1.76 times for a similar comparison.

Neumann et al.(6) observed losses of $14.36 \%$ for silage covered with polyethylene film and $11.21 \%$ losses for silage that used a barrier film for sealing, in addition to demonstrating the efficiency of dry matter recovery with the use of a barrier film, which was $7.54 \%$ higher in the upper layer compared to the polyethylene film, demonstrating the efficiency of the plastic film in blocking oxygen.

The ruminal dry matter disappearance rate, represented in Figure 1, was influenced by the different plastic films used to seal the silages and showed an increasing linear behavior with extending the ruminal incubation time. The DF200 $\mu \mathrm{m}$ and DFBO films provided the highest rates of initial degradation (33.99\% and $33.68 \%$, respectively) and 48 -hour degradation of corn silage $(74.80 \%$ and $76.70 \%$, respectively), standing out in relation to the silage stored with DF110 $\mu \mathrm{m}$ film.

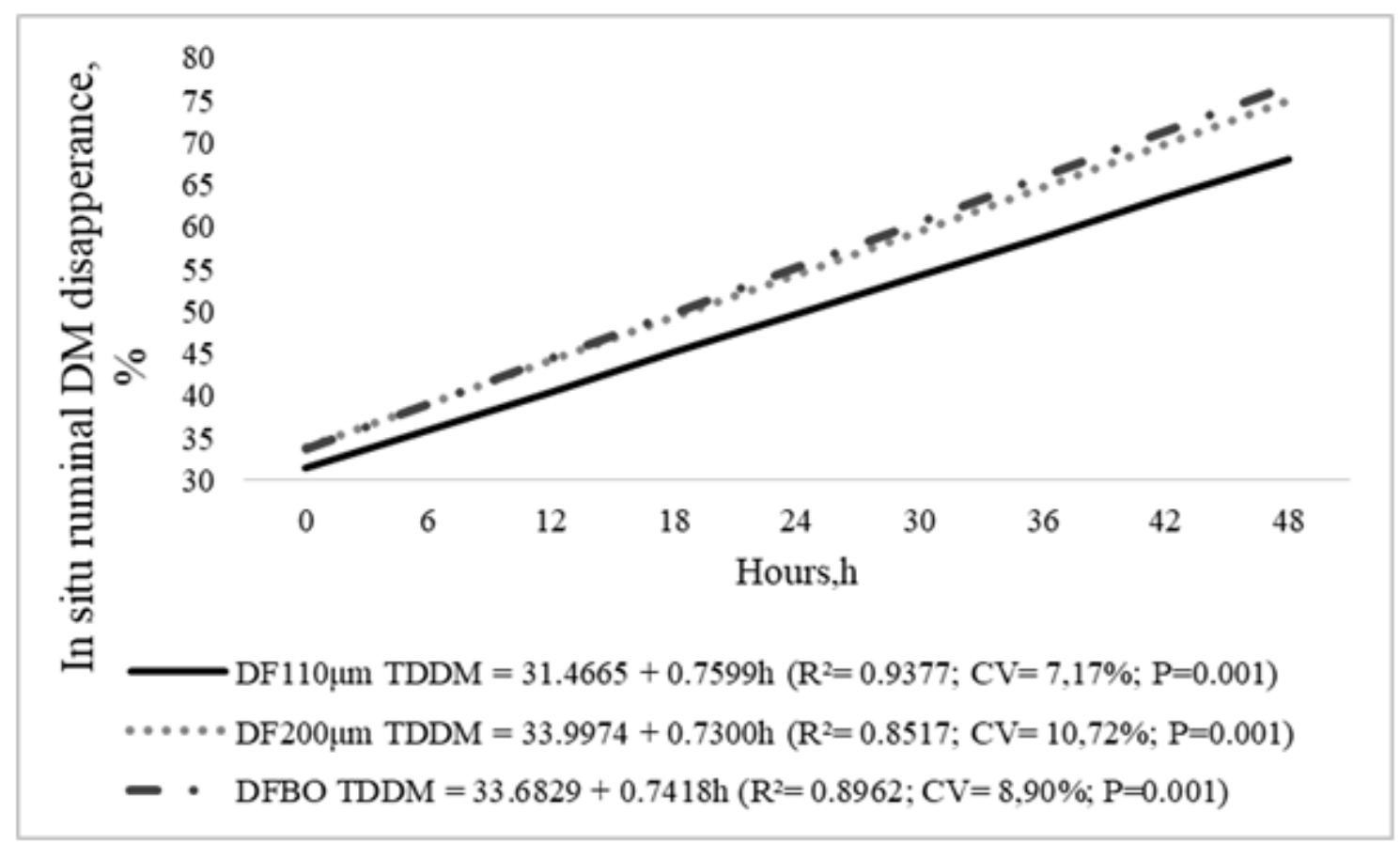

Figure 1. In situ ruminal dry matter disappearance rate of corn silages stored in bunker silos sealed with different double-sided plastic films. 
DF110 $\mu \mathrm{m}$ presented the highest rate $\left(0.7599 \mathrm{~h}^{-1}\right)$, while silages sealed with DF200 $\mu \mathrm{m}$ and DFBO films presented similar values $\left(0.7300 \mathrm{~h}^{-1}\right.$ and $\left.0.7418 \mathrm{~h}^{-1}\right)$. However, in relation to the soluble portion, illustrated in Figure 1 , by hour 0, DF110 $\mu$ m presented the smallest soluble portion (31.4665) compared to the other films evaluated, a result that impacts the rumen disappearance in 48 hours, because despite the DF110 $\mu$ m presenting the highest rate of ruminal disappearance hour ${ }^{-1}$, the silage with this sealing obtained ruminal dry matter disappearance $11.43 \%$ lower than DFBO and $9.30 \%$ lower than DF200 $\mu \mathrm{m}$. These values support the better ability of these plastic films to preserve soluble fractions, due to the rapid establishment of the anaerobic condition and drop in $\mathrm{pH}$, stopping the breakdown of these carbohydrates through physiological processes relevant to the plant and the activity of aerobic microorganisms, in addition to improved fiber digestibility ${ }^{(8,6)}$.

The highest rumen disappearance rate directly results in the reduction of feed costs due to the better use of the silage provided, helping to enable the implementation of the use of plastic films with higher added $\operatorname{cost}^{(4.5)}$.

The $\mathrm{pH}$ index of corn silages presented in Table 3 was also influenced by the type of film used to seal the silos $(P<0.05)$. The DF110 $\mu \mathrm{m}$ film resulted in obtaining the silage with the highest $(\mathrm{P}<0.05) \mathrm{pH}$ value $(4.12)$ compared to DF200 $\mu \mathrm{m}$ (4.04) and DFBO (4.02), which did not differ from each other.

Table 3. Fermentation profile of corn silages stored in bunker silos sealed with different double-sided plastic films

\begin{tabular}{|c|c|c|c|c|c|c|}
\hline \multirow{2}{*}{ Parameter } & \multicolumn{3}{|c|}{ Plastic Films } & \multirow{2}{*}{ Mean } & \multirow{2}{*}{$\boldsymbol{P}$} & \multirow{2}{*}{ SEM } \\
\hline & DF110 $\mu \mathrm{m}$ & DF200 $\mu \mathrm{m}$ & DFBO & & & \\
\hline \multicolumn{7}{|c|}{$\left(\mathrm{g} \mathrm{kg}^{-1} \mathrm{DM}\right)$} \\
\hline pH. (index) & $4.12 \mathrm{a}$ & $4.04 \mathrm{~b}$ & $4.02 \mathrm{~b}$ & 4.06 & 0.0443 & 0.0148 \\
\hline Acetic acid & $4.75 \mathrm{a}$ & $4.40 \mathrm{a}$ & $5.10 \mathrm{a}$ & 4.75 & 0.7225 & 0.2102 \\
\hline Propanoic acid & $0.48 \mathrm{a}$ & $0.49 a$ & $0.53 a$ & 0.50 & 0.8450 & 0.0295 \\
\hline Ethanol & $1.31 \mathrm{a}$ & $1.05 \mathrm{~b}$ & $1.17 b$ & 1.18 & 0.0416 & 0.0151 \\
\hline
\end{tabular}

Means followed by different lowercase letters, in the same row, differ from each other by Tukey's Test ( $\rho$ $<0.05)$.

Higher $\mathrm{pH}$ values are directly related to the development of filamentous fungi and yeasts that use as substrate for their development, mainly lactic acid, resulting in an increase in $\mathrm{pH}$ and temperature. This culminates in the loss of aerobic stability, since this acid is the main responsible for the decline in $\mathrm{pH}$, which, in the plant, at the time of cutting, is around values close to 6 and should be reduced to values close to 4 for good silage preservation $(28,29,9)$. The presence of oxygen in the silo is one of the main factors that trigger the development of these microorganisms ${ }^{(28)}$, and the plastic film used to seal the silos can become the main entry point for oxygen in the ensiled material, thus reducing the carbon dioxide concentration inside the silo and the efficiency of forage preservation $^{(4,30)}$. 
The different plastic films did not promote changes in acetic acid and propanoic acid contents (Table 3). Acetic acid values within the typical concentration for this acid are around $4 \mathrm{~g} \mathrm{~kg}^{-1} \mathrm{DM}^{(31)}$. Nevertheless, according to Kung Junior et al. ${ }^{(32)}$, values for acetic acid from corn silage are around $1-3 \mathrm{~g} \mathrm{~kg}^{-1} \mathrm{DM}$. The values recommended by the authors are lower than those obtained in the present study. Also according to Daniel et al. ${ }^{(26)}$, values around $1-3 \mathrm{~g} \mathrm{~kg}^{-1} \mathrm{DM}$ acetic acid are related to resistance to aerobic deterioration, but values above $4 \mathrm{~g} \mathrm{~kg}^{-1} \mathrm{DM}$ can be harmful, causing increased nutrient loss and reduced dry matter intake.

Ethanol concentration varied according to the plastic film. DF200 $\mu \mathrm{m}$ and DFBO promoted lower ethanol contents (1.05 and 1.17) compared to DF110 $\mu \mathrm{m}$ (1.31). Volatile organic compounds, such as ethanol, originate through the conversion of soluble sugars present in the ensiled plant ${ }^{(33)}$. Although ethanol has a considerable concentration of energy, its high volatility can lead to considerable losses of energy from the silage, as this compound is lost to the environment even before the food is supplied to the animals, making alcoholic fermentation undesirable ${ }^{(28)}$. Therefore, it can be considered that the silage from the DF110 $\mu$ m treatment presented a less desirable fermentation profile compared to the other films due to the higher concentration of ethanol (Table 3 ), which may have been formed by the development of yeasts, which generate ethanol; according to Kung Junior et al. ${ }^{(32)}$, silages with an ethanol concentration close to $2 \%$ DM may present low aerobic stability.

According to Yoshii et al.(34), part of the ethanol that is not lost to the environment and is ingested by the animal is partially oxidized to acetate by rumen microorganisms, concomitantly increasing the production of methane, which can reduce the efficiency of energy use ${ }^{(35)}$. The presence of oxygen in the ensiled material due to sealing failures or delay in silo closure can result in lower concentrations of volatile fatty acids, indicating a less intense fermentation process and reflecting in the prolongation of the respiratory phase, due to the lack of anaerobiosis, depleting the fermentable substrates required by lactic acid bacteria(36).

It can be suggested that the higher concentration of ethanol in the DF110 $\mu$ m silage is related to an increase in the population of yeasts in the ensiled mass due to the low oxygen barrier capacity of $110 \mu \mathrm{m}$ polyethylene, and, as a co-product of the fermentation of these microorganisms, ethanol formation occurs (Table 3), in addition to the increase in temperature (Table 4). Another fact that corroborates this hypothesis is the higher $\mathrm{pH}$ values presented by the DF110 $\mathrm{mm}$ silage (Table 3), as these microorganisms use lactic acid, which is the main responsible for maintaining the low $\mathrm{pH}^{(37)}$.

Table 4 lists the mean values of dry matter, silage temperature, temperature gradient and physical dry matter losses during the period of use of corn silages stored in bunker silos and sealed with different double-sided plastic films. 
Table 4. Mean values of dry matter, silage temperature, temperature gradient and physical dry matter losses during the period of use of corn silages stored in bunker silos sealed with different double-sided plastic films

\begin{tabular}{|c|c|c|c|c|}
\hline \multirow{2}{*}{$\begin{array}{l}\text { Period of } \\
\text { Evaluation }\end{array}$} & \multicolumn{3}{|c|}{ Plastic Films } & \multirow{2}{*}{ Mean } \\
\hline & DF110 $\mu \mathrm{m}$ & 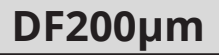 & DFBO & \\
\hline & \multicolumn{4}{|c|}{ Dry Matter (\%) } \\
\hline 0 to 28 days & 44.09 & 43.99 & 43.83 & $43.97 \mathrm{~A}$ \\
\hline 29 to 56 days & 43.36 & 44.15 & 42.58 & $43.36 \mathrm{~A}$ \\
\hline 57 to 84 days & 44.13 & 44.64 & 42.27 & $43.68 \mathrm{~A}$ \\
\hline \multirow[t]{2}{*}{ Mean } & $43.86 \mathrm{a}$ & $44.26 \mathrm{a}$ & $42.89 \mathrm{~b}$ & \\
\hline & \multicolumn{4}{|c|}{ Silage Temperature $\left({ }^{\circ} \mathrm{C}\right)$} \\
\hline 0 a 28 days & 23.24 & 19.11 & 21.22 & $21.19 \mathrm{~B}$ \\
\hline 29 to 56 days & 24.59 & 20.48 & 22.16 & $22.41 \mathrm{~B}$ \\
\hline 57 to 84 days & 26.20 & 24.98 & 26.11 & $25.76 \mathrm{~A}$ \\
\hline \multirow[t]{2}{*}{ Mean } & $24.68 \mathrm{a}$ & $21.52 \mathrm{~b}$ & $23.16 a b$ & \\
\hline & \multicolumn{4}{|c|}{ Temperature gradient $\left({ }^{\circ} \mathrm{C}\right)$} \\
\hline 0 to 28 days & 8.49 & 4.77 & 7.21 & $6.82 \mathrm{~A}$ \\
\hline 29 to 56 days & 8.38 & 4.27 & 5.95 & $6.20 \mathrm{~A}$ \\
\hline 57 to 84 days & 6.17 & 4.95 & 6.07 & $5.73 \mathrm{~A}$ \\
\hline Mean & $7.68 \mathrm{a}$ & $4.66 \mathrm{~b}$ & $6.41 \mathrm{ab}$ & \\
\hline \multicolumn{5}{|c|}{ Physical dry matter losses ( $\left.\mathrm{g} \mathrm{kg}^{-1} \mathrm{DM}\right)$} \\
\hline 0 to 28 days & 195.6 & 45.9 & 41.2 & $94.2 \mathrm{~B}$ \\
\hline 29 to 56 days & 195.6 & 59.8 & 111.0 & $122.1 \mathrm{~A}$ \\
\hline 57 to 84 days & 179.9 & 108.8 & 134.3 & $141.0 \mathrm{~A}$ \\
\hline Mean & $190.4 a$ & $71.5 \mathrm{~b}$ & $95.4 \mathrm{~b}$ & \\
\hline
\end{tabular}

Means followed by different lowercase letters, in the same row, or by different uppercase letters, in the same column, differ from each other by Tukey's test $(\rho<0.05)$.

Sealing with DFBO had the lowest $(\mathrm{P}<0.05)$ dry matter content $(42.89 \%)$ compared to DF200 $\mu \mathrm{m}$ and DF110 $\mu \mathrm{m}$ (44.26\% and 43.86\%, respectively). In turn, they did not differ from each other, but there was no variation in dry matter content as a function of the evaluation period.

Silage temperature was affected by the type of film used. Polyethylene DF110 $\mu \mathrm{m}$ resulted in a higher temperature compared to DF200 $\mu \mathrm{m}\left(24.68^{\circ} \mathrm{C}\right.$ and $21.52^{\circ} \mathrm{C}$, respectively), and the temperature gradient was also higher compared to DF $200 \mu \mathrm{m}\left(7.68^{\circ} \mathrm{C}\right.$ and $4.66^{\circ} \mathrm{C}$, respectively). Amaral et al.(37) and Borreani et al.(3) report that the use of oxygen barrier films allow lower silage temperatures compared to films that have only polyethylene in their composition, mainly at low thicknesses, unlike what was found in the present study, in which the use of barrier film caused no statistical difference for temperature and temperature gradient $\left(23.16^{\circ} \mathrm{C}\right.$ and $6.41^{\circ} \mathrm{C}$, respectively) compared to films composed exclusively of polyethylene in different thicknesses.

The temperature also varied according to the evaluation period, with the first and second periods $\left(21.19^{\circ} \mathrm{C}\right.$ and $22.41^{\circ} \mathrm{C}$, respectively) showing lower mean temperatures than the third period $\left(25.76^{\circ} \mathrm{C}\right)$.

The increase in silage temperature is related to the microbial activity of the ensiled 
mass, as the high rate of multiplication and growth of these microorganisms results in heat production, raising the silage temperature and breaking the aerobic stability, reducing its preservation potential|(38).

Physical losses of corn silage varied according to the type of plastic film used in sealing, and the silage sealed with DF110 $\mu \mathrm{m}$ had the highest physical losses (190.4 $\left.\mathrm{g} \mathrm{kg}^{-1} \mathrm{DM}\right)$ and lost $118.9 \mathrm{~g} \mathrm{~kg}^{-1} \mathrm{DM}$ more compared to DFBO and $95 \mathrm{~g} \mathrm{~kg}^{-1} \mathrm{DM}$ more compared to DF1 10 $\mu \mathrm{m}$ and DF200 $\mu \mathrm{m}$. In turn, physical losses of silages did not differ ( $>0.05)$ for the use of DFBO and DF200 $\mu \mathrm{m}$ films.

Physical losses also varied according to the evaluation period, so that in the first evaluation period, there were the lowest physical losses ( $\left.9.42 \mathrm{~g} \mathrm{~kg}^{-1} \mathrm{DM}\right)$ and with the advancement of the experimental periods, there was an increase in losses $\left(12.21 \mathrm{~g} \mathrm{~kg}^{-1}\right.$ DM and $14.10 \mathrm{~g} \mathrm{~kg}^{-1} \mathrm{DM}$, respectively for the second and third periods), indicating that, according to the increase in days, after opening the silo and exposure to oxygen, there was an increase in losses.

Wang et al. ${ }^{(39)}$ compared plastic films composed exclusively of polyethylene to oxygen barrier films and found that the silage sealed with the polyethylene film lost 6.2 percentage units more organic matter compared to the impermeable film. Furthermore, according to the authors, the use of barrier film brought economic benefits in the order of US\$ 0.74 for each ton of ensiled crop.

Plastic films with low oxygen and water barrier capacity stimulate the growth of unwanted microorganisms and favor silage spoilage, however, prior to the appearance of visible deterioration, the silage has already undergone several changes such as temperature increase, $\mathrm{pH}$ increase, increase of dry matter losses, culminating in the reduction of acceptance and intake of matter, reducing production performance ${ }^{(8)}$. Tabacco et $a l^{\left({ }^{(40)}\right)}$ reported that the increase in silage temperature due to the activity of aerobic microorganisms generates a reduction of up to $16 \%$ in the nutritional value of the silage. Hoffman and Combs ${ }^{(41)}$ also state that an increase of approximately $8^{\circ} \mathrm{C}$ in the temperature of 1 ton of silage can consume $6.3 \mathrm{Mcal}$ energy, which may result in a reduction of $4 \mathrm{~kg}$ milk for each ton silage that presents high temperatures.

Pitt and Muck ${ }^{(42)}$ point out that it is necessary to respect the daily silo feed out rate, without disturbing the rest of silage located inside the silo, because when the silo silage feed out management is ignored, associated with sealing failure, there may be an increase in oxygen penetration into the rest of the silo, in addition to contributing to an increase in silage disposal. The loss due to the disposal of deteriorated silage can reach up to four times more than the costs of purchasing plastic films for sealing the silos, demonstrating that this practice becomes viable and is essential for the proper preservation of the silage.

The DM contents during the aerobic stability evaluation showed linear growth according to the evaluation time (Figure 2). Silage sealed with the DF110 $\mu \mathrm{m}$ film had the highest moisture loss rate $\left(0.0232\right.$ points DM hour $\left.{ }^{-1}\right)$ compared to the sealing with DF200 $\mu \mathrm{m}$ (0.0223 points DM hour $\left.{ }^{-1}\right)$ and DFBO (0.0202 points DM hour $\left.{ }^{-1}\right)$.

The highest dehydration rate obtained by the silage sealed with the DF110 $\mu \mathrm{m}$ film may 
be related to fungal growth, as, for this to happen, a source of nitrogen, energy and oxygen is basically needed. In addition to these requirements, the moisture present in the material can be a determining factor in favoring initial fungal growth and, later, opportunistic bacteria that are capable of causing deleterious effects on the food preservation capacityand negatively affecting the animal use and performance ${ }^{(37)}$.

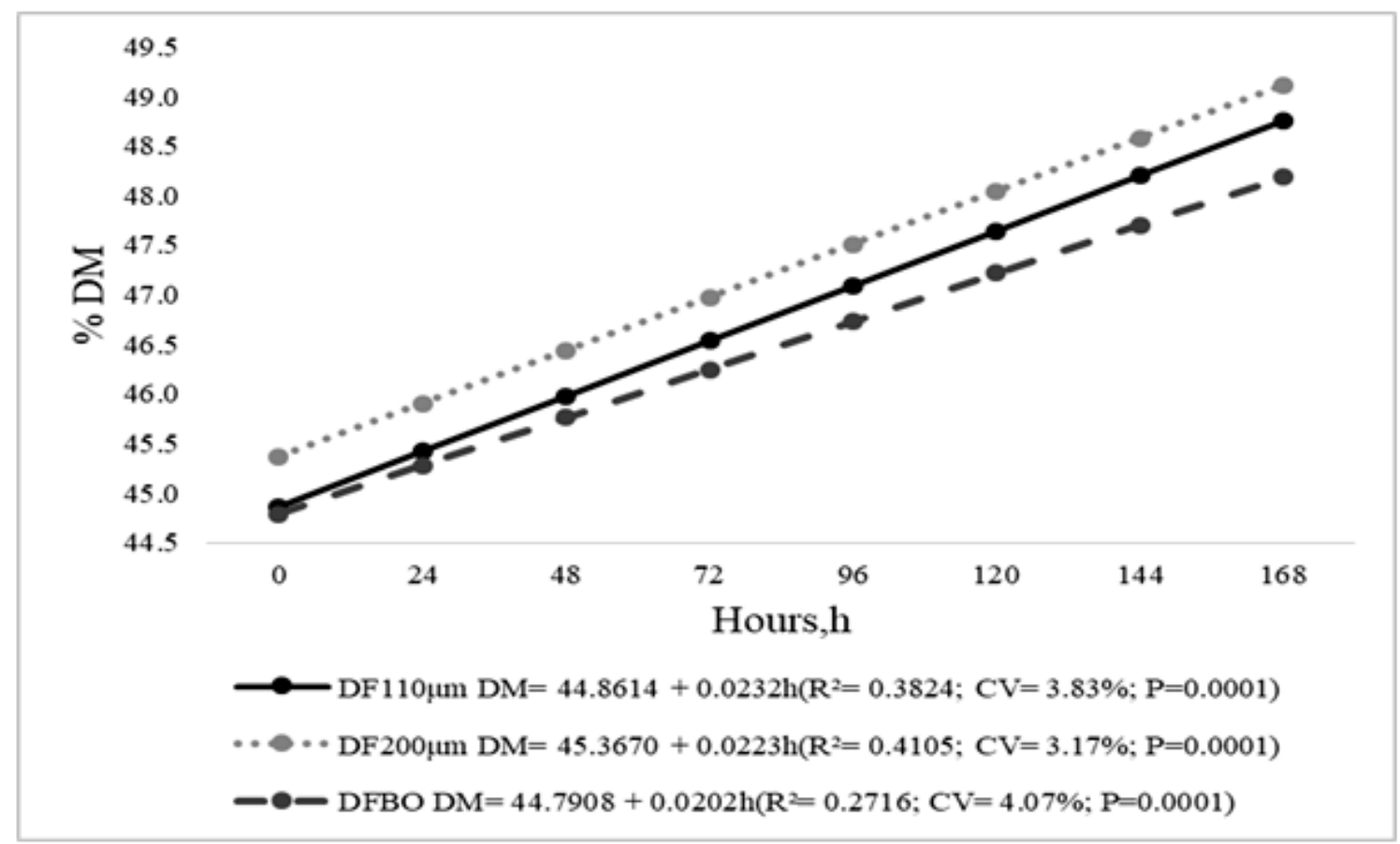

Figure 2. Dry matter contents during aerobic stability evaluation of corn silages stored in bunker silos sealed with different double-sided plastic films.

Silage temperature during the aerobic stability evaluation period, shown in Figure 3A, presented a linear increasing behavior for all tested films. Silages from the sealing with DF200 $\mu \mathrm{m}$ and DFBO films showed the highest temperature increments $\left(0.0292^{\circ} \mathrm{C}\right.$ hour ${ }^{1}$ and $\left.0.0276^{\circ} \mathrm{C}_{\text {hour }}{ }^{-1}\right)$ compared to DF110 $\mu \mathrm{m}$, which had the smallest temperature increment $\left(0.0193^{\circ} \mathrm{C}_{\text {hour }}{ }^{-1}\right)$. This behavior is repeated for the $\mathrm{pH}$ of corn silages (Figure $3 \mathrm{~B})$, as there was a linear increase in the $\mathrm{pH}$ with advancing days of aerobic stability. The greatest increase in $\mathrm{pH}$ in relation to the time the evaluation was also observed for silages coming from the sealings with the DF200 $\mu \mathrm{m}$ and DFBO films (0.0080 and 0.0043 pH points hour $\left.{ }^{-1}\right)$.

The more abrupt rise, both in temperature and $\mathrm{pH}$, comes from silages sealed with DF200 $\mu \mathrm{m}$ and DFBO films, which can be explained by the better internal environment of the silo during the fermentation and storage period. Due to the low concentration of oxygen in these silos, aerobic microorganisms completely cease their activities and, consequently, there is greater preservation of soluble carbohydrates. However, when these silages are exposed to oxygen after opening the silo, the microorganisms present in the ensiled mass return to their growth, which can be faster compared to silages 
that had a high amount of oxygen during storage, as a large part of the substrate used by aerobic microorganisms for their multiplication has already been used during the storage period. This process causes an increase in temperature due to the intense growth of these microorganisms and an increase in $\mathrm{pH}$ resulting from the breakdown of lactic acid, the main compound for maintaining low pH values ${ }^{(43)}$.

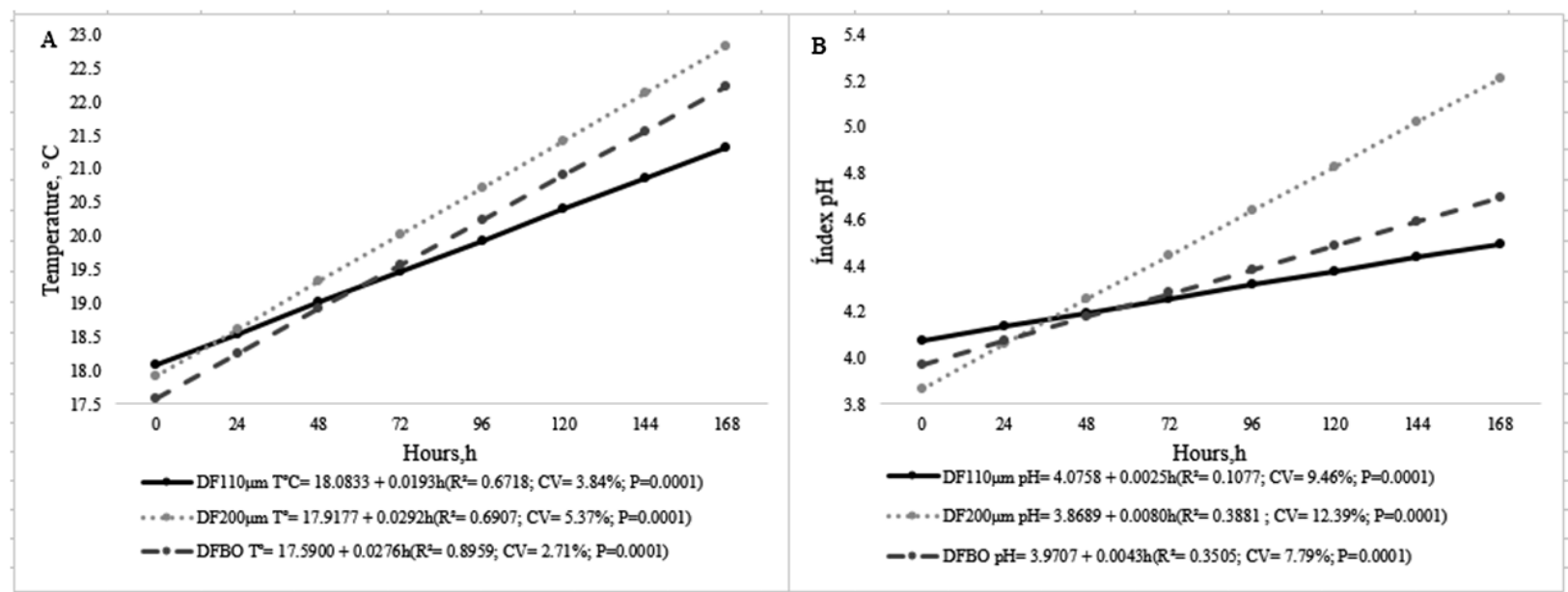

Figure 3. Silage temperature (A) and $\mathrm{pH}$ (B) during the aerobic stability evaluation of corn silages stored in bunker silos sealed with different doublesided plastic films.

The silage from the sealing with the DF110 $\mu \mathrm{m}$ film reached the maximum temperature in a shorter period (77 hours) compared to the sealing with DF200 $\mu \mathrm{m}$ and DFBO films (Table 5), and for the sealing with DF200 $\mu$ m, the maximum temperature of the silage occurred 48 hours after DF110 $\mu$ m, and for DFBO, 55 hours after the maximum temperature of the DF110 $\mu$ m silage.

Table 5. Time to reach maximum temperature, time to reach maximum $\mathrm{pH}$, time to loss aerobic stability by $\mathrm{pH}$ and time to loss aerobic stability by temperature during the aerobic stability evaluation period of corn silages stored in bunker silos sealed with different double-sided plastic films

\begin{tabular}{ccccccc}
\hline \multirow{2}{*}{ Parameter } & \multicolumn{3}{c}{ Plastic Films } & \multirow{2}{*}{ Mean } & P & \multirow{2}{*}{ SEM } \\
\cline { 2 - 4 } & DF110 $\boldsymbol{\mu} \mathbf{m}$ & DF200 $\boldsymbol{\mu m}$ & DFBO & & \\
\hline TTmax. (h) & $77.0 \mathrm{~b}$ & $128.0 \mathrm{a}$ & $132.0 \mathrm{a}$ & 108.3 & 0.0024 & 5.0211 \\
TpHmax. (h) & $111.0 \mathrm{a}$ & $124.0 \mathrm{a}$ & $119.0 \mathrm{a}$ & 118.0 & 0.6405 & 5.6599 \\
EST. (h) & $99.0 \mathrm{~b}$ & $105.0 \mathrm{ab}$ & $127.0 \mathrm{a}$ & 100.3 & 0.0468 & 3.9977 \\
ESpH. (h) & $159.0 \mathrm{a}$ & $128.0 \mathrm{~b}$ & $156.0 \mathrm{ab}$ & 147.7 & 0.0262 & 4.2054 \\
\hline
\end{tabular}

* TTmax: Time to reach maximum temperature; TpHmax: Time to reach maximum pH; EST: Aerobic stability by temperature; ESpH: Aerobic stability by $\mathrm{pH}$; h: Hours.

Means followed by different lowercase letters, in the same row, or by different uppercase letters, in the same column, differ from each other by Tukey's test $(\rho<0.05)$. 
Effects on the time to reach the maximum temperature reinforce the data in Figure 2 A, as the greater supply of food for the yeasts in silages sealed with the DF200 $\mu \mathrm{m}$ and DFBO films resulted in an extension of the time to reach the maximum temperature with a constant increase. Another fact that can be pointed out is that the DF110 $\mu \mathrm{m}$ film silage came from the silo with higher temperatures compared to the silages sealed with the other plastic films (Table 4).

Regarding the breakdown of aerobic stability, taking into account the temperature of the silage, the use of the DFBO film had the longest time to break the stability compared to DF110um (127 hours and 99 hours, respectively). Borreani and Tabacco ${ }^{(44)}$ report that increasing the impermeability of plastic films was one of the advances that made it possible to maintain aerobic stability for a longer period. Borreani et al.(3) found that polyethylene plastic film had a permeability of $990 \mathrm{~cm}^{3}$ per $\mathrm{m}^{2}$ for 24 hours at $1 \mathrm{bar}$, while the oxygen barrier film, composed of a combination of polyamide and polyethylene, had a permeability of $100 \mathrm{~cm}^{3}$ per $\mathrm{m}^{2}$ for 24 hours at 1 bar. Snell et al. ${ }^{(45)}$ also reported that the oxygen permeability of polyethylene films is related to their thickness, as the authors evaluated the oxygen permeability of polyethylene films with a thickness of 90, 150 and $200 \mu \mathrm{m}$ and found values of 459,258 and $188 \mathrm{~cm}^{3}$ per $\mathrm{m}^{2}$ in 24 hours, respectively, indicating that, for the same type of material, oxygen permeability is inversely proportional to the film thickness.

Borreani et al. (3) attested that films combining polyamide and polyethylene were more effective in maintaining the aerobic stability of the silage compared to conventional polyethylene films. Bernardes et al.(27) concluded that films with polyamide in their composition, in addition to improving the aerobic stability of the silage, enabled lower $\mathrm{pH}$ (Table 3), in agreement with the present study. The authors also related the better hygienic quality of the silage, due to the lower yeast count in the silage sealed with the polyamide film. Borreani and Tabacco et al.(46) related high counts of fungi and yeasts in silage with heating of the ensiled mass in the silo, suggesting that the higher silage temperature (Table 4) and lower aerobic stability of the silage sealed with the DF110 $\mu \mathrm{m}$ film (Table 5) can be attributed to the higher oxygen permeability of this film.

Considering $\mathrm{pH}$ for breaking aerobic stability (Table 6), the silage covered with the DF200 $\mu \mathrm{m}$ film had the lowest aerobic stability (128 hours), which differed from the seal with the DF110 $\mu \mathrm{m}$ film (159 hours), while the sealing with the DFBO film did not differ statistically $(P>0.05)$ from the other films evaluated, destabilizing after 156 hours from the beginning of the evaluation. This result complements the higher rates of $\mathrm{pH}$ increase hour-1 shown in Figure 3B, which allows the lactic acid content in the silage to be attributed to the silage $\mathrm{pH}$ increments, as yeasts present in the material ensiled use this acid as a substrate for their development, causing an increase in $\mathrm{pH}$ and loss of silage preservation capacity ${ }^{(47,43)}$.

In a second moment, the increase in $\mathrm{pH}$ may occur due to the breakdown of more complex structures, such as proteins, generating ammonia nitrogen and resulting in greater loss of nutrients ${ }^{(48)}$. Thus, it is possible to suggest that the silages from sealing

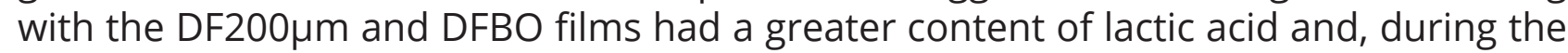
period of aerobic stability evaluation, there was an intense consumption of this acid, 
Effect of different double-sided plastic films on chemical and fermentation characteristics of corn silage Cristo $\mathrm{F} \mathrm{B}$ et al.

resulting in greater increments of $\mathrm{pH}$ and temperature hour ${ }^{-1}$.

\section{Conclusion}

The use of DF200 $\mu \mathrm{m}$ and DFBO films is recommended, as they resulted in the best ruminal disappearance rate of dry matter, $\mathrm{pH}$, temperature, physical losses of dry matter and aerobic stability of corn silage stored in bunker silos.

\section{Conflict of interests}

The authors declare no conflict of interest.

\section{References}

1. Oliveira CA, Millen DD, Survey of the nutritional recommendations and management practices adopted by feedlot cattle nutritionists in Brazil. Animal Feed Science Technology. 2014;197: 64-75. English. Available in: https://doi.org/10.1016/j.anifeedsci.2014.08.010

2. Silva MSJD, Jobim CC, Poppi EC, Tres TT, Osmari MP. Production technology and quality of corn silage for feeding dairy cattle in Southern Brazil. Revista Brasileira de Zootecnia. 2015; 44(9): 303-313. English. Available in: https://doi.org/10.1590/S1806-92902015000900001

3. Borreani G, Tabacco E, Cavallarin L. A new oxygen barrier film reduces aerobic deterioration in farmscale corn silage. Journal of Dairy Science. 2007; 90(10): 4701-4706. English. Available in: https://doi. org/10.3168/jds.2007-0310

4. Borreani G, Tabacco E. Improving corn silage quality in the top layer of farm bunker silos through the use of a next generation barrier film with high impermeability to oxygen. Journal Dairy Science. 2014; 97(4): 2415-2426. English. Available in: https://doi.org/10.3168/jds.2013-7632

5. Ferraretto LF, Shaver RD. Effects of whole-plant corn silage hybrid type on intake, digestion, ruminal fermentation, and lactation performance by dairy cows through a meta-analysis. Journal of Dairy Science. 2015; 98(4): 2662-2675. English. Available in: https://doi.org/10.3168/jds.2014-9045

6. Neumann M, Leão GFM, Askel EJ, Marafon F, Figueira DN, Poczynek M. Sealing type effect on corn silage quality in bunker silos. Ciência Rural. 2017; 47(5): 1-6. English. Available in: https://doi.org/10.1590/0103$\underline{8478 \mathrm{cr} 20160643}$

7. Neumann M, Leão GFM, Santos LC, Marafon, F, Askel EJ. Double seal in corn silage in confined cattle production. Revista de Ciências Agroveterinárias (Journal of Agroveterinary Sciences). 2018; 17(1): 100106. Portuguese. Available in: https://doi.org/10.5965/223811711712018100

8. Bernardes, TF. Advances in Silage Sealing. In: Da Silva T, Santos EM. Advances in Silage Production and Utilization. 1 ed. Rijeka, Croatia: InTech; 2016. p. 53-62. English. Available in:(https://www.intechopen. com/books/advances-in-silage-production-and-utilization/advances-in-silage-sealing).

9. Wilkinson JM, Fenlon JS. A meta-analysis comparing standard polyethylene and oxygen barrier film in terms of losses during storage and aerobic stability of silage. Grass and Forage Science. 2014; 69(3): 385-392. English. Available in: https://doi.org/10.1111/gfs.12087

10. Pott CA, Müller MML, Bertelli PB. Green manuring as an agroecological alternative for the recovery of soil fertility. Revista Ambiência. 2007; 3(1): 51-63. Portuguese. Available in: https://revistas.unicentro.br/ index.php/ambiencia/article/view/300/412 
Effect of different double-sided plastic films on chemical and fermentation characteristics of corn silage Cristo F B et al.

11. Brazilian Society of Soil Science. State Center Paraná. Fertilization and Liming Manual for the State of Paraná. - Curitiba:SBCS/NEPAR; 2017. 301 p. Portuguese. Available in:https://www.sbcs.org.br/index. php?route=product/product\&product_id=136

12. AOAC Association of Official Analytical Chemists. Official Methods of Analysis of the Association of Official Analytical Chemists, 16th edition, Association of Official Analytical Chemists. Arlington, V.A., U.S.A. 1995. English. Available in: https://www.aoac.org/journal-of-aoac-international/

13. Neumann M, Sandini IE, Ost PR, Falbo MK, Lustosa SBC, Pellegrini LG. feedlot performance of steers fed with silages of corn and of sorghumassociated with three levels of concentrate. Revista Brasileira de Milho e Sorgo, Sete Lagoas. 2007; 6(3): 365-378. Portuguese. Available in: https://doi.org/10.18512/19806477/rbms.v6n03p\%25p

14. Cherney JH, Cherney DJR. Assessing Silage Quality. In: Buxton DR, Muck RE, Harrison HJ. Silage Science and Technology. 4nd ed. American Society of Agronomy, Inc., Crop Science Society of America, Inc., Soil Science Society of America, Inc. 2003. p. 141-198. English. Available in: (https://acsess.onlinelibrary. wiley.com/doi/pdf/10.2134/agronmonogr42.c4)

15. Silva DJ, Queiroz AC. Análise de alimentos, métodos químicos e biológicos. $3^{a}$ reimpressão. Universidade Federal de Viçosa; 2009. 235p. Portuguese. Available in: https://www.editoraufv.com.br/ produto/analise-de-alimentos-3-edicao/1108830

16. Van Soest PJ, Robertson JB, Lewis BA. Methods for dietary fiber, neutral detergent fiber, and nonstarch polysaccharides in relation to animal nutrition. Journal of Dairy Science. 1991; 74(10): 3583-3597. English. Available in: https://doi.org/10.3168/jds.S0022-0302(91)78551-2

17. Goering HK, Van Soest PJ, Forage fiber analysis: apparatus reagents, procedures and some applications. Agricultural Handbook. 1970. p.379. English. Available in: https://books.google.com.br/books?hl=pt-BR \&l $r=\& i d=2 B j F v E o n a H o C \& o i=f n d \& p g=P A 1 \& d q=G o e r i n g+H K,+V a n+S o e s t+P J,+F o r a g e+f i b e r+a n a l y s i s:+a p p$ aratus+reagents, + procedures+and+some+applications.+Agricultural+Handbook.+1970.+p.379.+\&ots=m NWMXpHJqX\&sig=eLL9DhSM6Mm58bIGBv-QXhkynIs\#v=onepage\&q\&f=false

18. Bolsen KK, Ashbell G, Weinberg ZG. Silage fermentation and silage additives-Review. Asian-Australasian journal of animal sciences. 1996; 9:483-494. English. Available in: https://doi.org/10.5713/ajas.1996.483

19. Nocek JE. In situ and other methods to estimate ruminal protein and energy digestibility: a review. Journal of Dairy Science. 1988; 71(8): 2051-2069. English. Available in: https://doi.org/10.3168/jds. S0022-0302(88)79781-7

20. Price JDA. Modification of the Barker - Summer son Method for the Determination of Lactic Acid. Afialyst. 1969; 94(1125): 1151-1152. English. Available in: https://doi.org/10.1039/AN9699401151

21. Kung Junior L, Robinson JR, Ranjit NK, Chen JH, Golt CM, Pesek JD, Microbial populations, fermentation end-products, and aerobic stability of corn silage treated with ammonia or a propionic acid-based preservative. Journal of Dairy Science. 2000; 83(7): 1479-1486. English. Available in: https://doi. org/10.3168/jds.S0022-0302(00)75020-X

22. Weinberg ZG, Shatz O, Chen Y. Effect of lactic acid bacteria inoculants on in vitro digestibility of wheat and corn silages. Journal of Dairy Science. 2007; 90(10): 4754-4762. English. Available in: https://doi. org/10.3168/jds.2007-0176

23. Taylor CC, Kung Junior L. The effect of Lactobacillus buchneri 40788 on the fermentation and aerobic stability of high moisture corn in laboratory silos. Journal of Dairy Science. 2002; 85(6): 1526-1532. English. Available in: https://www.journalofdairyscience.org/article/S0022-0302(02)74222-7/pdf

24. SAS Institute. Sas/Stat User'sguide:statistics, version 6. 4.ed. North Caroline, Version 2. Cary (NC): SAS Insitute Inc., 1993. 943p. English. Available in: (https://www.ncbi.nlm.nih.gov/books/NBK7244/) 
Effect of different double-sided plastic films on chemical and fermentation characteristics of corn silage Cristo F B et al.

25. Machado, J. Filmes de vedação na conservação de silagem de milho para bovinos de corte em terminação. Maringá, 34 f. Dissertação (Mestrado) - Programa de Pós Graduação em Zootecnia, Produção Animal, Universidade Estadual de Maringá, Maringá, 2019. Portuguese. Available in: (http://sites.uem. br/ppz/trabalhos-de-conclusao/dissertacoes/2019/juliana-machado.pdf);(https://sucupira.capes.gov. br/sucupira/public/consultas/coleta/trabalhoConclusao/viewTrabalhoConclusao.jsf?popup=true\&id trabalho=6994113)

26. Daniel JLP, Bernardes TF, Jobim CC, Schmidt P, Nussio LG. Production and utilization of silages in tropical areas with focus on Brazil. Grass and Forage Science. 2019; 74(2): 188-200. English. Available in: https://doi.org/10.1111/gfs.12417

27. Bernardes TF, Nussio LG, Amaral RC. Top spoilage losses in maize silage sealed with plastic films with different permeabilities to oxygen. Grass and Forage Science. 2012; 67(1); 34-42. English. Available in: https://doi.org/10.1111/j.1365-2494.2011.00823.x

28. Bernardes TF, Daniel JLP, Adesogan AT, Mcallister TA, Drouin P, Nussio LG, Huhtanen P, Tremblay GF, Bélanger G, Cai Y. Silage review: Unique challenges of silages made in hot and cold regions. Journal of dairy science. 2018; 101(5): 4001-4019. English. Available in: https://doi.org/10.3168/jds.2017-13703

29. Borreani G, Dolci P, Tabacco E, Cocolin L. Aerobic deterioration stimulates outgrowth of spore-forming Paenibacillus in corn silage stored under oxygen-barrier or polyethylene films. Journal Dairy Science. 2013; 96(8): 5206-5216. English. Available in: https://doi.org/10.3168/jds.2013-6649

30. Gallo A, Guibert G, Frisvad JC, Bertuzzi T, Nielsen KF. Review on mycotoxin issues in ruminants: occurrence in forages, effects of mycotoxin ingestion on health status and animal performance and practical strategies to counteract their negative effects. Toxins. 2015; 7(8): 3057-3111. English. Available in: https://doi.org/10.3390/toxins7083057

31. Kleinschmit DH, Kung Junior L. A Meta-Analysis of the Effects of Lactobacillus buchneri on the Fermentation and Aerobic Stability of Corn and Grass and Small-Grain Silages. Journal of Dairy Science. 2006; 89(10): 4005 - 4013. English. Available in: https://doi.org/10.3168/jds. S0022-0302(06)72444$\underline{4}$

32. Kung Junior L, Shaver RD, Grant RJ, Schmidt RJ. Silage review: Interpretation of chemical, microbial, and organoleptic components of silages. Journal of dairy Science. 2018; 101(5): 4020-4033. English. Available in: https://doi.org/10.3168/jds.2017-13909

33. Daniel JLP, Capelesso A, Cabezas-Garcia EH, Zopollatto M, Santos MC, Huhtanen P, Nussio LG. Fibre digestion potential in sugarcane across the harvesting window. Grass and Forage Science. 2014; 69(1); 176-181. English. Available in: https://doi.org/10.1111/gfs.12044

34. Yoshii T, Asanuma N, Hino T. Effect of ethanol on nitrate and nitrite reduction and methanogenesis in the ruminal microbiota. Animal Science Journal. 2005; 76(1): 37-42. English. Available in: https://doi. org/10.1111/j.1740-0929.2005.00235.x

35. Daniel JLP, Amaral RC, Neto AS, Cabezas-Garcia EH, Bispo AW, Zopollatto M, Cardoso TL, Spoto MHF, Santos FAP, Nussio LG. Performance of dairy cows fed high levels of acetic acid or ethanol. Journal of Dairy Science. 2013; 96(1): 398-406. English. Available in: https://doi.org/10.3168/jds.2012-5451

36. Kim SC, Adesogan AT. Influence of ensiling temperature, simulated rainfall, and delayed sealing on fermentation characteristics and aerobic stability of corn silage. Journal of Dairy Science. 2006; 89(8): 3122-3132. English. Available in: https://doi.org/10.3168/jds.S0022-0302(06)72586-3

37. Amaral RC, Santos MC, Daniel JLP, Sá Neto A, Bispo AW, Cabezas-Garcia EH, Nussio LG. The influence of covering methods on the nutritive value of corn silage for lactating dairy cows. Revista Brasileira de Zootecnia. 2014; 43; 471-478. English. Available in: https://doi.org/10.1590/S1516-35982014000900003

38. Pahlow G, Muck RE, Driehuis F, Elferink SJWHO, Spoelstra SF. Microbiology of ensiling. Agronomy. 42; 
Effect of different double-sided plastic films on chemical and fermentation characteristics of corn silage Cristo F B et al.

\section{1-94. English. Available in: https://doi.org/10.2134/agronmonogr42.c2}

39. Wang K, Uriarte ME, Li SC, Rich K, Banchero C, Bu DP, Wilkinson JM, Bolsen KK. Effect of type of underlay film on fermentation profile, nutritional quality and estimated loss of organic matter in the outer layer of whole-plant maize ensiled in large bunker silos. Grass and Forage Science. 2017; 72(4): 772-776. English. Available in: https://doi.org/10.1111/gfs.12283

40. Tabacco E, Righi F, Quarantelli A, Borreani G. Dry matter and nutritional losses during aerobic deterioration of corn and sorghum silages as influenced by different lactic acid bacteria inocula. Journal of Dairy Science. 2011; 94(3): 1409-1419. English. Available in: https://doi.org/10.3168/jds.2010-3538

41. Hoffman PC, Combs DK. Molds and mycotoxins in corn silage and high moisture corn. Part I. Managing aerobic stability. Department of Dairy Science, University of Wisconsin-Madison, 2009. English. Available in: http://dysci.wisc.edu/uwex/brochures/brochures/hoffmold.pdf

42. Pitt RE, Muck RE. A diffusion model of aerobic deterioration at the exposed face of bunker silos. Journal of Agricultural Engineering Research, 1993; 55(1): 11-26. English. Available in: https://doi.org/10.1006/ jaer.1993.1029

43. WilkinsonJM, Davies DR. The aerobic stability of silage: key findings and recent developments. Grass and Forage Science. 2013; 68(1): 1-19. English. Available in: https://doi.org/10.1111/j.1365-2494.2012.00891.x

44. Borreani G, Tabacco E. Plastics in animal production, In: ORZOLEK, M. (Ed.). A Guide to the Manufacture, Performance, and Potential of Plastics in Agriculture. 9nd ed. Amsterdam: Elsevier Ltd., 2017. p. 145-185. English. Available in: https://www.sciencedirect.com/book/9780081021705/a-guide-to-the-manufactureperformance-and-potential-of-plastics-in-agriculture

45. Snell HGJ, Oberndorfer C, Lücke W, Van Den Weghe HFA. Effects of the colour and thickness of polyethylene film on ensiling conditions and silage quality of chopped maize, as investigated under ambient conditions and in mini-silos. Grass and Forage Science. 2002; 57(4): 342-350. English. Available in: https://doi.org/10.1046/j.1365-2494.2002.00334.x

46. Borreani G, Tabacco E. Low permeability to oxygen of a new barrier film prevents butyric acid bacteria spore formation in farm corn silage. Journal of Dairy Science. 2008; 91(11): 4272-4281. English. Available in: https://doi.org/10.3168/jds.2008-1151

47. Rabelo CHS, Rezende AV, Nogueira DA, Rabelo FHS, Senedese SS, Vieira PF, Barbolsa LA, Carvalho A. Losses fermentative and aerobic stability of corn silages inoculated with lactic acid bacterial in different maturity stages. Revista Brasileira de Saúde e Produção Animal. 2012; 13(3); 656-668. English. Available in: https://doi.org/10.1590/S1519-99402012000300006

48. Lima EM, Jayme DG, Silva FCO, Micheli PHF, Cortes IHG, Anjos GVS, Silva NTA, Ottoni D. Aerobic deterioration of silages. Electronic Journal Nutritime. 2015; 12(2): 3996-4003. English. Available in: https:// www.nutritime.com.br/arquivos internos/artigos/ARTIGO299.pdf 